Review

\title{
A Disease in Search for a Biomarker: MicroRNAs in Parkinson's Disease
}

\author{
Aimee Rodica Chiș ${ }^{\text {I,2 }}$, Alexandra Ioana Moatăr ${ }^{\text {I,2 }}$ and Ioan-Ovidiu Sîrbu ${ }^{\text {I,2,* }}$ \\ I Department of Biochemistry, "Victor Babeș” University of Medicine and Pharmacy, 30004I Timișoara, Romania; \\ chis.aimee@umft.ro (A.R.C.); moatar.alexandra@umft.ro (A.I.M.) \\ ${ }^{2}$ Center for Complex Networks Science, "Victor Babeș” University of Medicine and Pharmacy, \\ 30004I Timissoara, Romania \\ * Correspondence: ovidiu.sirbu@umft.ro
}

Submitted: I4 May 202I; Accepted: 29 May 202I; Published: 25 June 202I

\begin{abstract}
This review discusses the current research data on using microRNAs as biomarkers for the diagnostics and screening of Parkinson's Disease (PD). We provide a comprehensive, critical analysis of the overwhelmingly diverse data on circulant microRNAs associated with PD. We also highlight the possible underlying molecular pathogenesis-related circulant microRNAs in the context of the natural history of PD.
\end{abstract}

Keywords: Parkinson's Disease; microRNA; biomarker

How to cite: Chiș, A.R.; Moatăr, A.I.; Sîrbu, I.-O. A Disease in Search for a Biomarker: MicroRNAs in Parkinson's Disease. Timisoara Med. 202I, 202I(I), 2; doi:I0.35995/tmj20210102.

\section{Introduction}

With a worldwide yearly incidence of up to 35 new cases/roo,ooo individuals, Parkinson's Disease (PD) is the second most common neurodegenerative disease after Alzheimer's. Its global burden is predicted to double by 2030 . PD is a disease of the elderly ( $>65$ years of age), its prevalence increasing abruptly up to $3 \%$ in individuals $>80$ years of age $[\mathrm{I}, 2]$. The incidence of $\mathrm{PD}$ varies depending on sex (more common in men), race (less common in African Americans), ethnicity (more frequent in Ashkenazi Jews, Inuit, and Alaska Natives), and environment (e.g., exposure to pesticides) [3].

The diagnosis of PD is essentially clinical, based on non-motor (hyposmia, constipation, sleep disorder, cognitive decline, and psychiatric disturbances) and motor (rigidity, rest tremor, postural instability, and bradykinesia) symptoms [4]. The therapeutic response (rapid improvement of motor symptoms) to levodopa, the assessment of cardiac sympathetic denervation (by myocardial scintigraphy with iodine-I23-meta-iodobenzylguanidine), and the dopamine transporter single-photon emission computed tomography (DaT SPECT) are valuable tests for defining PD diagnostics. However, they cannot differentiate PD from parkinsonism involving the dysfunction of dopamine transport $[5,6]$. Usually, at the time of diagnosis, half of the dopaminergic neurons are already lost in the substantia nigra in patients with motor signs [7].

Most patients with PD respond well to dopamine substitution therapy, the off periods and dyskinesia appearing within 2 to 6 years after the onset of levodopa therapy [4]. There are no biochemical or molecular bona 
fide biomarkers for PD diagnosis, therapy monitoring, or prognostic evaluation. Intensely investigated in the last decade, blood, saliva, and cerebrospinal fluid (CSF) $\alpha$-synuclein have proven to lack specificity and sensitivity $[8,9]$.

MicroRNAs are endogenous small non-coding RNAs involved in post-transcriptionally regulating gene expression. A single microRNA modulates the stability of hundreds of mRNAs, while one mRNA might interact with multiple target mRNAs, a biunivocal relationship that explains the ability of microRNAs to regulate the expression of almost half of the human transcriptome [Io]. Due to their outstanding stability in various biological fluids, microRNAs are ideal biomarker candidates in a wide variety of pathologies, including neurodegenerative diseases [II].

The quest for a PD-related microRNA biomarker has led to an impressive amount of data, characterized by a bewildering lack of consistency/overlap, due to differences in methodologies, analytical platforms, target tissues (CSF, whole blood, plasma, and serum), and the ethnicity and staging of the included patients [I2]. Very few studies fulfill the requirements of a biomarker study in terms of design, the stringency of analysis, and the scale of patients' enrolment, which could explain why microRNAs have not reached the clinical setting. A basic analytical pipeline would include a screening step (usually next-generation sequencing (NGS), microarray, or RT-PCR array) followed by a validation step on a different technology (e.g., by qRT-PCR) and in an independent cohort; in both steps, stringent criteria of inclusion and the exclusion of both patients and controls and proper bioinformatics and statistical analysis are essential.

Here, we analyze the current published data describing the association of microRNA with PD and their application in diagnosis and therapy monitoring. We performed a systematic search on PubMed and Google Scholar using the search terms "Parkinson's" AND "microRNA" AND "human", further refined by "cerebrospinal fluid", "whole blood", "plasma", "serum”, and "PBMC”. We restricted our search to human patients and included only statistically significant data from original research papers (thus excluding review papers and meta-analyses). We recorded the microRNA ID, the method of screening/detection, the direction of deregulation, the size of the cohorts analyzed, and the DOI.

\section{Cerebrospinal Fluid}

There are several arguments in favor of using CSF to analyze differentially expressed microRNAs in PD: it is in direct communication with the extracellular space of the brain and, given the blood-brain barrier (BBB), it reflects, almost exclusively, the brain physiology and pathology.

Burgos et al. (2014) compared postmortem microRNA profiles of CSF and serum in PD patients and identified a specific, stage- and time-dependent microRNA PD signature. Interestingly, the authors found that CSF microRNAs are slightly more stable and consistent than serum in discriminating PD versus controls. Unexpectedly, none of the microRNAs identified after miRDeep2 analysis with DESeq2 normalization were validated by qRT-PCR [13]. Of note, there is a limited overlap between the CSF and serum microRNAs, which raises questions regarding the utility of serum microRNA in exploring PD biology, given that BBB alterations do not influence the (lack of) correlation between the CSF and the blood compartments [I4].

Gui et al. isolated CSF exosomes and used low-density TaqMan arrays to describe a profound alteration of the microRNA profile in PD patients: 16 upregulated and II downregulated. Furthermore, eight microRNAs (miR-I, miR-I53, miR-409-3p, miR-19b-3p, miR-Ioa-5p, miR-136-3p and miR-433 and let-7g-3p) were further validated by individual qRT-PCR assays in independent samples, arguing for the validity of the data [I5]. 
Marques et al. used a targeted approach to monitor the expression of 19 microRNAs in the CSF of PD patients. They found that miR-24 (age-independently) and miR-20s (age-dependently) discriminate with a relatively modest accuracy between PD and control samples [i6].

In a (very) preliminary study, Qin et al. (2019) describe a consistent downregulation of hsa-miR-626 in the CSF of sporadic PD patients versus Alzheimer's disease (AD) and controls; however, the small size of the cohorts and the control group consisting of encephalitis and Guillain-Barre syndrome patients influence the validity of this microRNA as a diagnostic biomarker [I7].

Caldi et al. sequenced small RNAs isolated from extracellular vesicles in the CSF of PD patients. They demonstrated, using a machine learning approach, that miR-I26-5p (the most discriminative), miR-99a-5p, and miR-5oI-3p (the least discriminative) could differentiate between PD and control samples, a feature validated in an independent cohort of probands [18].

Dos Santos et al. identified a panel of 5 microRNAs (Let-7f-5p, miR-27a-3p, miR-I25a-5p, miR-Isia-3p, and miR-423-5p) with over $90 \%$ sensitivity in discriminating between early PD and healthy controls; interestingly, when combined with $\alpha$-synuclein, the discriminating power rose to $97 \%$ sensitivity, $90 \%$ specificity, and $96 \%$ AUC [19].

Overall, 56 unique microRNAs were found to be differentially regulated in the CSF of PD patients, of which only 9 overlap: let-7b-5p, let-7g-3p, miR-ioa-5p, miR-I27-3p, miR-136-3p, miR-I84, miR-19b-3p, miR-409-3p, and miR-99a-5p. Furthermore, except for let-7g-3p (upregulated), miR-I84 (upregulated), and miR-99a-sp (downregulated), the other overlapping microRNAs showed divergent changes (Table $\mathrm{I}$ ). All these discrepancies might be due to differences in the PD cohorts analyzed (e.g., postmortem vs. vivo, stage, length of disease, and exosomes vs. whole CSF) and/or the stringency of the normalization procedures. It is currently difficult to discern whether exosome-related microRNAs are superior markers compared to whole CSF, given that the permeability of the $\mathrm{BBB}$ for microRNAs is a phenomenon that is currently not fully understood; brain-derived microRNAs can reach the periphery, while astrocytes and microglia take up peripheral microRNAs [20].

\section{Whole Blood}

Margis et al. were the first to show that whole blood microRNAs can be used to differentiate between PD and control samples: miR-I, miR-22*, and miR-29 distinguished untreated PD from controls, while miR-16-2*, miR-26a2*, and miR $30 a$ identified treated from untreated patients. Interestingly, the authors demonstrate that Levodopa therapy also increased the expression of miR-I, miR-22*, and miR-29, which decreased in untreated patients, suggesting that miR upregulation in response to $\mathrm{PD}$ substitutive therapy might be a rather large phenomenon. To our knowledge, this is the first study investigating the possible role of Levodopa in modulating the expression of microRNAs in biological fluids [2r]. 
Table I. Altered microRNA expression in CSF from PD patients.

\begin{tabular}{|c|c|c|c|c|}
\hline miR & Change & Analytical Platform & Cohort Size & Ref. \\
\hline hsa-mir-626 & Down & RT-PCR (TaqMan) & I5 PD, 16 controls & [18] \\
\hline hsa-mir-626 & Down & RT-PCR (TaqMan) & $20 \mathrm{PD}, 27$ controls & {$[17]$} \\
\hline $\begin{array}{l}\text { miR-19a-3p } \\
\text { let-7g-3p } \\
\text { miR-19b-3p } \\
\text { miR-3oa-3p } \\
\text { miR-3oe-3p } \\
\text { miR-338-3p }\end{array}$ & Up & \multirow[b]{2}{*}{$\begin{array}{l}\text { NGS (Illumina TruSeq } \\
\text { Small RNA sequencing) }\end{array}$} & \multirow[b]{2}{*}{$65 \mathrm{PD}, 70$ controls } & \multirow[b]{2}{*}[\mathrm{I}_{3}]{} \\
\hline $\begin{array}{l}\text { miR-1oa-5p } \\
\text { miR-1224-5p } \\
\text { miR-127-3p } \\
\text { miR-128 } \\
\text { miR-132-5p } \\
\text { miR-136-3p } \\
\text { miR-16-2-3p } \\
\text { miR-2I2-3p } \\
\text { miR-37o } \\
\text { miR-409-3p } \\
\text { miR-43I-3p } \\
\text { miR-4448 } \\
\text { miR-485-5p } \\
\text { miR-873-3p }\end{array}$ & Down & & & \\
\hline miR-24 & Down & \multirow[t]{2}{*}{ RT-PCR (TaqMan) } & \multirow[t]{2}{*}{$28 \mathrm{PD}, 28$ controls } & \multirow[t]{2}{*}{ [16] } \\
\hline miR-20s & Up & & & \\
\hline $\begin{array}{l}\text { let-7g-3p } \\
\text { miR-ioa- } 5 \mathrm{p} \\
\text { miR-136-3p } \\
\text { miR-153 } \\
\text { miR-409-3p } \\
\text { miR-433 }\end{array}$ & Up & \multirow[t]{2}{*}{$\begin{array}{l}\text { Low-density qPCR array } \\
\text { (TaqMan)/qRT-PCR } \\
\text { (TaqMan) }\end{array}$} & \multirow[t]{2}{*}{$47 \mathrm{PD}, 27$ controls } & \multirow[t]{2}{*}[15]{} \\
\hline $\begin{array}{l}\text { miR-I } \\
\text { miR-Igb-3p }\end{array}$ & Down & & & \\
\hline $\begin{array}{l}m i R-7-5 p \\
\text { miR-33I-5p } \\
\text { miR-Io6b- } 5 \mathrm{p} \\
\text { miR-I84 } \\
\text { miR-2I8-5p }\end{array}$ & Up & \multirow[t]{2}{*}{$\begin{array}{l}\text { Exiqon miRCURY PCR } \\
\text { array/qRT-PCR } \\
\text { (TaqMan) }\end{array}$} & \multirow[t]{2}{*}{$\begin{array}{l}\text { Io } \mathrm{PD} \text {, io controls for } \\
\text { discovery lot; } \\
37 \mathrm{PD}, 23 \text { controls for } \\
\text { validation lot }\end{array}$} & \multirow[t]{2}{*}{ [19] } \\
\hline $\begin{array}{l}\text { miR-99a-sp } \\
\text { let-7b-5p } \\
\text { miR-33I-5p }\end{array}$ & Down & & & \\
\hline
\end{tabular}


Table i. Cont.

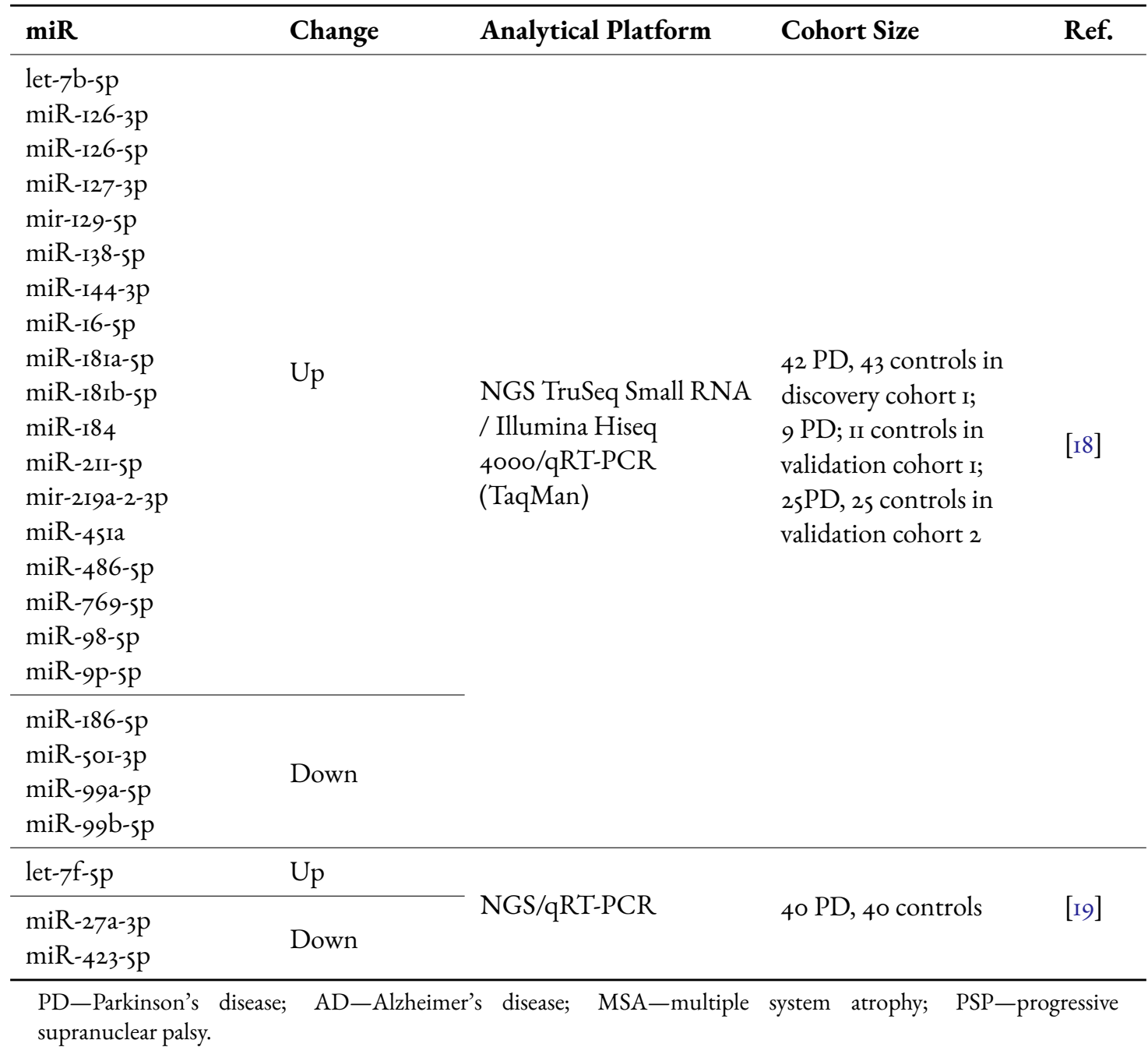

\section{Plasma}

An interesting approach, targeted on brain-enriched microRNA present in plasma samples has been recently published, highlights the differential expression of five microRNAs: miR-22-3p, miR-I24-3p, miR-I36-3p, miR-I54-5p, and miR-323a-3p. The authors describe higher levels of miR-33o-5p, miR-433-3p, and miR-495-3p in male probands but found no statistical correlation of any of these microRNAs with any clinical features (age-at-onset, duration of disease, UPDRS III, MMSE, LEDD, and on/off state) of $\mathrm{PD}$ patients [22]. Interestingly, the same group describes distinct microRNA fingerprints for idiopathic and genetic (alpha-synuclein $\mathrm{A}_{53} \mathrm{~T}$ and glucocerebrosidase) PD patients, indicating that the pathogenetic mechanisms have a significant impact on microRNA release in circulation. miR-7-5p, miR-22-3p, miR-I24-3p, miR-136-3p, miR-139-5p, miR-330-5p, miR-433-3p, and miR-495-3p were all upregulated in idiopathic PD, I2 microRNAs were deregulated in glucocerebrosidase mutants (upregulated: miR-I32-3p, miR-43I-3p, and hsa-miR-433-3p; downregulated: miR-I28-3p, miR-136-3p, miR-I54-5p, miR-323a-3p, miR-338-3p, miR-382-5p, miR-409-3p, miR-4Io-3p, and miR-485-5p), and $\mathrm{I}_{2}$ microRNAs were deregulated in alpha-synuclein $\mathrm{A}_{53} \mathrm{~T}$ patients (upregulated: miR-I24-3p, miR-I32-3p, and miR-433-3p; downregulated: miR-22-3p, miR-I28-3p, miR-136-3p, miR-I54-5p, miR-323a-3p, miR-382-5p, miR-409-3p, miR-4Io-3p, and miR-485-5p). Of note, miR-433-3P was significantly upregulated in all three forms of $\mathrm{PD}$ analyzed. The discrimination performance 
of these microRNAs (individually or combined) is rather modest, and none of them correlates with the sex of the probands, disease duration, patients' ON/OFF status, MMSE, or UPDR scale. However, overall, miR-22-3p, miR-124-3p, and miR-I39-5p showed a significant correlation with age [23].

A very interesting exploratory study by Grossi et al. found a significant upregulation of miR-34a-5p in a subset (small size) of extracellular vesicles (EV) from the plasma of PD patients; notably, although the discrimination power is rather modest $(A U C=0.74)$, the change is associated with the length and staging (Hoehn and Yahr, $\mathrm{H}-\mathrm{Y}$ ) of the disease (suggesting accumulation along with evolution), and the Beck Depression Inventory score. Surprisingly, however, there are no significant correlations with the patients' age at disease onset, the dosage of levodopa, or unified Parkinson's disease rating (UPDR) scale. Of significant interest is the authors' finding that small EVs contain more microRNAs than the other subsets [24]. This result contrasts with and complements the data from Cosin-Tomas et al. describing no change in miR-34a-5p in the plasma of PD patients [25].

Cardo et al. analyzed (by PCR array followed by qRT-PCR validation) a small cohort of patients and described a significant upregulation of miR-33I-5p [26]. In yet another targeted approach looking into microRNAs modulating $\alpha$-synuclein expression, miR-433 and miR-I33b were found to be downregulated in the plasma of PD patients, but with no correlation with neither the age nor stage of the disease [27]. Two microRNAs highly enriched in adult brain structures and known for their involvement in PD pathogenesis were found to be dysregulated in PD plasma by Li et al.: miR-I37 (upregulated) and miR-I24 (downregulated) distinguished between PD and controls, although no correlation with neither the UPDRS score nor H-Y stage could be evidenced [28].

In a rather unusual analysis, Khoo et al. combined k-Top Scoring Pairs (k-TSP) and significance analysis of microarrays (SAM) to identify a set of 13 differentially regulated microRNAs, of which miR-I826/miR-45ob-3p), miR-626, and miR-505 have the highest predictive power and highest sensibility and sensitivity in the discovery cohort. Unfortunately, none of these characteristics hold up after the analysis of the validation lot [29].

In one of the very few published analyses of plasma from naïve PD patients, Chen et al. describe a set of five deregulated microRNAs able to discriminate between PD and controls with surprisingly good accuracy $($ AUC $>0.8)[30]$.

Uwatoko et al. used microarray to comparatively analyze microRNA expression in PD and MSA and describe a significant (correlated) upregulation of miR-19b-3p and miR-24-3p and downregulation of miR-67i-5p, which has discriminatory power between the two related pathologies [3I].

miR-IO5-5p was found to be strongly overexpressed in PD patients and could discriminate (although with relatively modest accuracy, AUC $=0.768$ ) PD from healthy controls but did not correlate with the disease's length or severity [32].

Overall, 44 unique microRNAs were found to be differentially regulated in the plasma of PD patients, of which I4 overlap between at least two studies: miR-I24-3p, miR-I28-3p, miR-I32-3p, miR-136-3p, miR-I54-5p, miR-22-3p, miR-222, miR-323a-3p, miR-382-5p, miR-409-3p, miR-4IO-3p, miR-433-3p, miR-485-5p, and miR-67I-5p. The changes in miR-I24-3p, miR-I32-3p, miR-433-3p expression (upregulated), miR-I28-3p, miR-136-3p, miR-I54-5p, miR-323a-3p, miR-382-5p, miR-409-3p, miR-4Io-3p, and miR-485-5p (downregulated) are concordant; the other overlapping microRNAs show divergent changes (Table 2). 
Table 2. Altered microRNA expression in plasma from PD patients.

\begin{tabular}{|c|c|c|c|c|}
\hline miR & Change & Analytical Platform & Cohort Size & Ref \\
\hline miR-34a-sp & $\mathrm{Up}$ & qRT-PCR (TaqMan) & Is PD, I4 controls & [24] \\
\hline $\begin{array}{l}\text { miR-22-3p } \\
\text { miR-139-5p } \\
\text { miR-154-5p } \\
\text { miR-330-5p }\end{array}$ & Up & qRT-PCR, SYBR-Green & Io9 PD, 92 controls & [22] \\
\hline $\begin{array}{l}\mathrm{miR}-433 \\
\mathrm{miR}-\mathrm{I} 33 \mathrm{~b}\end{array}$ & Down & qRT-PCR (FastGreen) & $46 \mathrm{PD}, 49$ controls & {$[27]$} \\
\hline miR-137 & Up & \multirow{2}{*}{ qRT-PCR (SYBRGreen) } & \multirow{2}{*}{ 6o PD, 60 controls } & \multirow[t]{2}{*}{ [28] } \\
\hline miR-I24 & Down & & & \\
\hline $\begin{array}{l}\text { miR-1307 } \\
\text { miR-647 } \\
\text { miR-548b-3p } \\
\text { miR-192* } \\
\text { miR-505 } \\
\text { miR-506 } \\
\text { miR-626 } \\
\text { miR-1826 } \\
\text { miR-572 } \\
\text { miR-671-5p } \\
\text { miR-222 } \\
\text { miR-9* } \\
\text { miR-1225-5p }\end{array}$ & - & $\begin{array}{l}\text { Agilent microarray/qRT-PCR } \\
\text { (TaqMan) }\end{array}$ & $\begin{array}{l}32 \mathrm{PD}, 32 \text { controls (discovery lot); } \\
42 \mathrm{PD}, 30 \text { controls (validation lot) }\end{array}$ & [29] \\
\hline $\operatorname{miR}-27 \mathrm{a}$ & Up & & & \\
\hline $\begin{array}{l}\text { let-7a } \\
\text { let-7f } \\
\text { miR-I42-3p } \\
\text { miR-222 }\end{array}$ & Down & PCR array (SYBR Green) & 25 naïve $\mathrm{PD}, 25$ controls & [30] \\
\hline $\begin{array}{l}m i R-124-3 p \\
m i R-132-3 p \\
m i R-132-3 p \\
m i R-136-3 p \\
m i R-139-5 p \\
m i R-22-3 p \\
m i R-330-5 p \\
m i R-431-3 p \\
m i R-433-3 p \\
m i R-495-3 p \\
m i R-7-5 p\end{array}$ & Up & \multirow{2}{*}{$\begin{array}{l}\text { qRT-PCR } \\
\text { (SYBRGreen) }\end{array}$} & \multirow{2}{*}{$\begin{array}{l}99 \text { PD idiopathic, } 53 \text { PD genetic, Ioo } \\
\text { controls }\end{array}$} & \multirow{2}{*}[23]{} \\
\hline $\begin{array}{l}\text { miR-128-3p } \\
\text { miR-136-3p } \\
\text { miR-136-3p } \\
\text { miR-I54-5p } \\
\text { miR-22-3p } \\
\text { miR-323 } \alpha-3 p \\
\text { miR-338-3p } \\
\text { miR-382-5p } \\
\text { miR-409-3p } \\
\text { miR-4IO-3p } \\
\text { miR-485-5p }\end{array}$ & Down & & & \\
\hline miR-67I-5p & Down & \multirow{2}{*}{$\begin{array}{l}\text { Exiqon miRCURY } \\
\text { microarray/qRT-PCR (SYBR } \\
\text { Green) }\end{array}$} & \multirow{2}{*}{$\begin{array}{l}\text { II MSA, } 3 \text { controls in the discovery lot; } \\
\text { 6I MSA, } 28 \text { PD, } 28 \text { controls in the } \\
\text { validation lot }\end{array}$} & \multirow[b]{2}{*}{ [32] } \\
\hline $\begin{array}{l}\text { miR-19b-3p } \\
\text { miR-24-3p }\end{array}$ & Up & & & \\
\hline miR-I05-sp & Up & qRT-PCR & $319 \mathrm{PD}, 578$ controls & {$[32]$} \\
\hline
\end{tabular}

PD_Parkinson's disease; AD-Alzheimer's disease; MSA-multiple system atrophy; PSP-progressive supranuclear palsy. 


\section{Serum}

Serum miR-133b, which is strongly downregulated in PD patients, is correlated with serum ceruloplasmin, a molecule believed to be involved in PD pathogenesis [33]. Dong et al. used Solexa sequencing to analyze a rather large set of PD patients and identified a set of four downregulated microRNAs (miR-I4I, miR-2I4, miR-I46b-5p, and miR-193a-3p), which could differentiate between HY stage I and 2 [34].

Shu et al. show a strong downregulation of miR-I32-3p and miR-I46-5p in PD samples; both microRNAs are positively correlated with disease severity and negatively correlated with Braak staging [35].

There is a surprising concordance between serum and CSF microRNAs in the data of Burgos et al. (2014); except for miR-1294, all serum microRNAs (miR-16-2-3p, miR-30a-3p, miR-3oe-3p, and miR-338-3p) were dysregulated in the same direction in the CSF. None of them correlated with Braak stages, neurofibrillary tangle score, or plaque density score [13].

Vallelunga et al. aimed to differentiate between PD and MSA and found that when compared to controls, PD serum was enriched in mir-24, miR-223, and miR-324-3p and had lower levels of miR-3oc and miR-148b. At the same time, in comparison with MSA, miR-24, miR-34b, and miR-I $48 \mathrm{~b}$ are upregulated [36].

A carefully designed study of serum microRNAs in idiopathic and genetic (LRRK2 G2OrgS mutation) PD identified four microRNAs downregulated in both forms of PD, miR-29a, miR-29c, miR-19b, and miR-19c, of which the first three were confirmed in two independent validation cohorts [37].

Bai et al. were among the few to consistently explore sex differences in the expression of miR-29 family microRNAs in the serum of PD patients; the authors describe a significant downregulation of miR-29 a, b, and c, and show that all three microRNAs are expressed at higher levels in female samples. Interestingly, the expression of miR-29a and miR-29c is inversely correlated with disease severity, suggesting they might serve as biomarkers for disease progression [38]. In an exciting follow-up on miR-29 family expression, the group of Jian Wang analyzed the expression of miR-29 in relation to cognitive impairment in PD patients; mir-29b seems to be the best performer: it discriminates the PD patients with dementia from non-dementia probands, and is associated with the global cognitive status and the z-scores of memory, language, and executive function. Surprisingly, none of the miR-29 family members were associated with any of the clinical features analyzed: age, sex, duration, staging, and severity of the disease [39].

Cao et al. describe a downregulation of miR-I9b and upregulation of miR-I95 and miR-24 in the exosome-like microvesicles purified from the serum of PD patients [40]. The expression of none of these microRNAs correlated with age, sex, smoking or drinking habits, or $\mathrm{H}-\mathrm{Y}$ scale. miR-24 showed the best diagnostic value $(A U C=0.908)$ and the best sensitivity and specificity values (8I.7\% and 85.0\%, respectively) [4I]

Ding et al. describe the deregulation of five microRNAs (miR-195, miR-I5b, miR-221, miR-18ra, and miR-185) in PD samples; although the individual sensitivity and specificity values do not surpass $76.9 \%$ and $86.8 \%$, respectively (the case of miR-I5b), altogether, this set of microRNAs can correctly classify $91 . . \%$ of PD cases $[40]$.

Ma et al. tested the ability of $\mathrm{I} 6$ serum PD-associated microRNAs to predict PD and found four microRNAs (miR-29c, miR-I46a, miR-2I4, and miR-22I) to be downregulated when compared to healthy controls. Out of these four candidates, miR-22I performed the best: $A U C=0.787$ and is positively correlated with UPDRS-III and UPDRS-V (although with modest scores) [42]. 
Jin et al. demonstrated elevated levels of miR-52od-5p in PD patients vs. controls and Alzheimer's disease or MSA patients and speculated upon the possible impact on alteration of ceruloplasmin levels; however, miR-52od-sp correlated with neither the severity nor motor phenotype of the disease [43].

Overall, 36 unique microRNAs were found to be differentially regulated in the serum of PD patients, of which Io overlap between at least two studies: miR-I4I, miR-I46b-5p, miR-193a-3p, miR-195, miR-19b, miR-2I4, miR-24, miR-29a, mir-29b, and miR-29c. All the changes are concordant: miR-195, miR-24 expression (upregulated), miR-I4I, miR-I46b-5p, miR-I93a-3p, miR-I9b, miR-2I4, miR-29a, mir-29b, and miR-29c (downregulated) (Table 3$)$.

Table 3. Altered microRNA expression in serum from PD patients.

\begin{tabular}{|c|c|c|c|c|}
\hline $\operatorname{miR}$ & Change & Analytical Platform & Cohort Size & Ref. \\
\hline $\begin{array}{l}\text { miR-I32-3p } \\
\text { miR-I46-5p }\end{array}$ & Down & qRT-PCR & $82 \mathrm{PD}, 44$ controls & {$[35]$} \\
\hline $\begin{array}{l}\mathrm{miR}-338-3 \mathrm{p} \\
\mathrm{miR}-3 \mathrm{aa}-3 \mathrm{p} \\
\mathrm{miR}-3 \mathrm{oe}-3 \mathrm{p}\end{array}$ & Up & \multirow{2}{*}{$\begin{array}{l}\text { NGS (Illumina } \\
\text { TruSeq Small RNA } \\
\text { sequencing) }\end{array}$} & \multirow[t]{2}{*}{ 5o PD, 62 controls } & \multirow[t]{2}{*}[\mathrm{I}3]{} \\
\hline $\begin{array}{l}\text { miR-I6-2-3p } \\
\text { miR-I294 }\end{array}$ & Down & & & \\
\hline miR-I33b & Down & qRT-PCR (TaqMan) & $46 \mathrm{PD}, 46$ controls & [34] \\
\hline $\begin{array}{l}\text { miR-I4I } \\
\text { miR-2I4 } \\
\text { miR-I46b-5p } \\
\text { miR-I93a-3p }\end{array}$ & Down & $\begin{array}{l}\text { Solexa } \\
\text { sequencing/qRT-PCR } \\
\text { (TaqMan) }\end{array}$ & $169 \mathrm{PD}$, I8o controls & [35] \\
\hline $\begin{array}{l}\operatorname{miR}-223 \\
\mathrm{miR}-324-3 \mathrm{p} \\
\mathrm{mir}-24\end{array}$ & Up & \multirow{2}{*}{$\begin{array}{l}\text { Low-density TaqMan } \\
\text { array/qRT-PCR }\end{array}$} & \multirow{2}{*}{$6 \mathrm{PD}, 5$ controls in discovery lot; $25 \mathrm{PD}$ and $25 \mathrm{ctrl}$ in validation lot } & \multirow{2}{*}{ [36] } \\
\hline $\begin{array}{l}\text { miR-339-5p } \\
\text { miR-3oc } \\
\text { miR-I } 48 b\end{array}$ & Down & & & \\
\hline $\begin{array}{l}\operatorname{miR}-29 a \\
\operatorname{miR}-29 c \\
\operatorname{miR}-19 b\end{array}$ & Down & $\begin{array}{l}\text { TaqMan MicroRNA } \\
\text { arrays/qRT-P R }\end{array}$ & 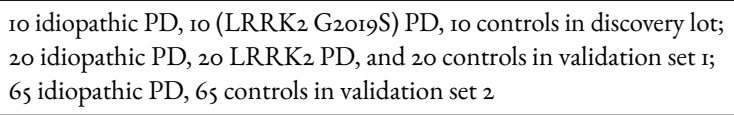 & [37] \\
\hline $\begin{array}{l}\operatorname{miR}-29 a \\
\operatorname{miR}-29 b \\
\operatorname{miR}-29 c\end{array}$ & Down & qRT-PCR & 8o PD and 8 o controls & {$[38]$} \\
\hline $\begin{array}{l}\operatorname{miR}-29 a \\
\operatorname{miR}-29 b \\
\operatorname{miR}-29 c\end{array}$ & Down & qRT-PCR & $\begin{array}{l}39 \text { PD PD-normal cognition, } 37 \text { PD-mild cognitive impairment, } 22 \\
\text { PD-dementia, } 40 \text { controls }\end{array}$ & [39] \\
\hline miR-ıgb & Down & \multirow{2}{*}{$\begin{array}{l}\text { qRT-PCR (SYBR } \\
\text { Green) }\end{array}$} & \multirow[b]{2}{*}{ Io9 PD, 40 controls } & \multirow[b]{2}{*}[4\mathrm{I}]{} \\
\hline $\begin{array}{l}\text { miR-I95 } \\
\text { miR-24 }\end{array}$ & Up & & & \\
\hline miR-I95 & Up & \multirow[b]{2}{*}{$\begin{array}{l}\text { Solexa } \\
\text { sequencing/qRT-PCR } \\
\text { (TaqMan) }\end{array}$} & \multirow[b]{2}{*}{ I06 PD, 9I controls in discovery lot; 6I PD, 55 controls in validation lot } & \multirow[b]{2}{*}{ [40] } \\
\hline $\begin{array}{l}\text { miR-I85 } \\
\text { miR-I5b } \\
\text { miR-22I } \\
\text { miR-I8Ia }\end{array}$ & Down & & & \\
\hline $\begin{array}{l}\operatorname{miR}-29 c \\
\text { miR-I46a } \\
\text { miR-214 } \\
\text { miR-22I }\end{array}$ & Down & \multirow[t]{2}{*}{ qRT-PCR (TaqMan) } & PD I38, il2 controls & [42] \\
\hline miR-s2od-sp & Up & & $46 \mathrm{PD}, 46$ controls & {$[43]$} \\
\hline
\end{tabular}




\section{Peripheral Blood Mononuclear Cells (PBMCs)}

Behbahanipour et al. used a qRT-PCR targeted approach to identify the deregulated PBMC expression of three microRNAs usually associated with aging and cellular senescence: miR-885 and miR-I7 (increased), and miR-36I (decreased). The combined analysis of all three microRNAs led to an astonishing level of discrimination between PD and controls, with an AUC of 0.985 [44].

Martins et al. used microarrays to identify an intriguing, strong downregulation of $\mathrm{I} 8$ microRNAs in PBMCs from PD patients; interestingly, the authors describe as the primary source of variation the affection status of the individuals included in the study [45].

A targeted RT-PCR array approach focused on the expression of miR-I55, miR-26a, miR-I46a, and miR-I32 in PBMCs of PD patients under substitutive therapy identified miR-I5s as a putative responder (downregulation) to Levodopa therapy [46]. Of note, miR-I5s is known for its role as a modulator of alpha-synuclein-induced inflammatory phenomena in $\mathrm{PD}[47]$.

Soreq et al. investigated the changes in microRNAs expression in the leucocytes of PD patients before and after one hour of deep brain electrical stimulation; when compared to healthy controls, the sets of microRNAs pre(I6 microRNA) and poststimulation (II microRNAs) have a surprisingly consistent overlap (five microRNAs), although with the inverse direction of change. It is thus surprising that pre- and poststimulation datasets show only one single overlap (although, again, the change is in opposite directions), miR-I43, the significance of which remains obscure. In a complex network analysis of microRNA-mRNA interactions pre- and postelectrical stimulation, the authors show that the interactions pattern change, with miR-320, miR-424, and miR-I43 occupying central positions [48].

Serafin et al. designed a targeted approach to identify the microRNAs differentially expressed in the PBMCs of treated vs. naïve (untreated) PD patients [49].

Fazeli et al. investigated the association of miR-27a-3p and miR-27b-3p with SRRM2 (an RNA splicing factor) in the early diagnostics of PD. Interestingly, both miR-27a-3p and miR-27b-3p show an age-dependent upregulation in healthy controls, which is abolished in PD miR-27b-3p (but not miR-27a-3p) and is inversely correlated with disease severity, and thus, might predict disease progression [5o].

Baghi et al. analyzed clinical samples and MPP+-treated $\mathrm{SHSY}_{5} \mathrm{Y}_{\text {cells }}$ and showed a strong upregulation of miR-376a in PBMCs, while MPP+-treated SHSY5Y cells showed a biphasic response: initial downregulation in acute MMP exposure followed by upregulation in chronic exposure. miR-376a is correlated with disease severity and has an acceptable AUC (o.8024); thus, it might serve as a diagnostic and prognostic biomarker for PD [sI].

Overall, 42 unique microRNAs were differentially regulated in the plasma of PD patients, none overlapping between at least two different studies (Table 4 ). 
Table 4. Altered microRNA expression in PBMCs from PD patients.

\begin{tabular}{|c|c|c|c|c|}
\hline $\operatorname{miR}$ & Change & Analytical Platform & Cohort Size & Ref. \\
\hline $\begin{array}{l}\text { miR-885 } \\
\text { miR-I7 }\end{array}$ & Up & \multirow[t]{2}{*}{ qRT-PCR } & \multirow[t]{2}{*}{36 PD, 16 controls } & \multirow[t]{2}{*}[45]{} \\
\hline miR-36I & Down & & & \\
\hline $\begin{array}{l}\text { miR-335 } \\
\text { miR-374a } \\
\text { miR-I99a-3p } \\
\text { miR-I99b-3p } \\
\text { miR-I26* } \\
\text { miR-I5I-3p } \\
\text { miR-I99a-5p } \\
\text { miR-I5I-5p }\end{array}$ & \multirow[b]{2}{*}{ Down } & \multirow[b]{2}{*}{$\begin{array}{l}\text { miRCURYTM LNA } \\
\text { microarray }\end{array}$} & \multirow[b]{2}{*}{${ }_{9} \mathrm{PD}, 13$ controls } & \multirow[b]{2}{*}{ [46] } \\
\hline $\begin{array}{l}\text { miR-ı26 } \\
\text { miR-29b } \\
\text { miR-I47 } \\
\text { miR-28-5p } \\
\text { miR-3ob } \\
\text { miR-374b } \\
\text { miR-19b } \\
\text { miR-30c } \\
\text { miR-29c } \\
\text { miR-3ora }\end{array}$ & & & & \\
\hline $\operatorname{miR}-26 a$ & Up & \multirow{2}{*}{$\begin{array}{l}\text { miScript miRNA PCR } \\
\text { Array }\end{array}$} & \multirow{2}{*}{37 PD, 43 controls } & \multirow{2}{*}[47]{} \\
\hline miR-I5s-5p & Down & & & \\
\hline $\begin{array}{l}\text { miR-I46a-sp } \\
\text { miR-Io3a-3p } \\
\text { miR-3ob-5p }\end{array}$ & Up & qRT-PCR (Taqman) & $\begin{array}{l}36 \text { treated-PD, ro independent } \\
\text { naïve } \mathrm{PD}, 36+\text { io controls }\end{array}$ & {$[50]$} \\
\hline $\begin{array}{l}\text { miR-29a-3p } \\
\text { miR-I8b } \\
\text { miR-20a } \\
\text { miR-2I } \\
\text { miR-150 } \\
\text { miR-199b } \\
\text { miR-378c } \\
\text { miR-67I } \\
\text { miR-I249 } \\
\text { miR-I274b }\end{array}$ & Up & \multirow[t]{2}{*}{$\begin{array}{l}\text { NGS (AP SOLiD } \\
\text { sequencer) }\end{array}$} & \multirow[t]{2}{*}{7 PD, 6 controls } & \multirow[t]{2}{*}{ [49] } \\
\hline $\begin{array}{l}\text { miR-4293 } \\
\text { miR-16 } \\
\text { miR-92b } \\
\text { miR-320a } \\
\text { miR-32ob } \\
\text { miR-320c }\end{array}$ & Down & & & \\
\hline $\mathrm{miR}-769$ & Up & \multirow{2}{*}{ qRT-PCR (SYBR Green) } & \multirow{2}{*}{$30 \mathrm{PD}, \mathrm{I} 4$ controls } & \multirow{2}{*}[\mathrm{sI}]{} \\
\hline$m i R-27 b-3 p$ & Down & & & \\
\hline $\begin{array}{l}\mathrm{miR}-27 \mathrm{a}-3 \mathrm{p} \\
\mathrm{miR}-376 \mathrm{a}\end{array}$ & Up & qRT-PCR (SYBR Green) & $33 \mathrm{PD}, 25$ controls & {$[52]$} \\
\hline
\end{tabular}

PD_Parkinson's disease. 


\section{Discussion}

Assaying microRNAs in the blood and its components is relatively simple, fast, inexpensive, and, above all, minimally invasive. Given the outstanding stability of microRNAs in the various biological fluids, it is tempting to search for microRNA signatures associated with a pathology known for its lack of a bona fide biomarker.

As mentioned in the introduction, the data from all these studies show a surprising lack of overlap among them, and a specific miRNA signature is basically impossible to describe. In our opinion, the main reason for this resides in the rather small size of cohorts and the heterogeneity of the probands (and controls) included in the analyses, which is not only due to the disease itself but also to the subjectivity of diagnostics. Next, the diverse source of biological fluids analyzed also plays an important role: CSF is richer in brain-derived microRNAs, while the serum content of small RNAs is significantly skewed by microRNA species associated with activation of platelets during coagulation [52]. From a technical point of view, the purification methods are known to influence both the yield and quality of the (small) RNA isolated. Of note, few data sets were obtained after checking for hemolysis (at least by monitoring oxyhemoglobin absorbance at 4I4nm), a factor known to significantly influence extracellular microRNA levels [53]. Next, the method for analysis of microRNA levels in biological fluids also affects the results. Used in basically all data sets analyzed, qRT-PCR (and, by extension, qRT-PCR arrays) represents (due to its sensitivity and specificity) the gold standard in assessing the expression of a microRNA in a tissue. Although they cannot match the sensitivity and specificity of qRT-PCR yet, NGS and microarray compensate by breadth and depth of investigation. Furthermore, there are issues related to the reproducibility and replicability of the high-throughput approaches (especially when dealing with low-input RNA samples); hence, validation by qRT-PCR is obligatory [54]. Finally, and often overlooked or scarcely approached, there is a (overly) broad spectrum of normalization procedures, including endogenous microRNA, endogenous non-microRNA molecules, and exogenous spiked-in microRNAs. Thus, it is of paramount importance to identify a (set of) microRNA with stable expression across all samples, independent (as much as possible) of age, sex, and physiological/pathological condition. In our opinion, and based on our experience, combining spike-ins with endogenous microRNAs produces the best results.

Overall, of all unique microRNAs found to be deregulated in biological fluids sampled from PD patients, $52.5 \%$ were upregulated, arguing (should other regulatory mechanisms, such as transcriptional activation by transcription factors of $\mathrm{CpG}$ methylation, be excluded) for a general, post-transcriptional inhibitory effect on gene target networks in PD pathology. This ratio (upregulated microRNAs/downregulated microRNAs $>\mathrm{I}$ ) is maintained in CSF (61.9\% upregulated) and plasma (64.7\%) PD samples; unexpectedly, the ratio is reverted in the serum (29\%) and PBMC (40.9\%), indicating significant differences in the microRNA's sources for the three blood components analyzed.

One should, nevertheless, note that, overall, there are 14 overlaps between the up- and downregulated microRNAs (let-7b-5p, miR-ioa-5p, miR-I27-3p, miR-132-3p, miR-i36-3p, miR-i9b-3p, miR-22-3p, miR-24, miR-27a-3p, miR-33I-5p, miR-338-3p, miR-409-3p, miR-43I-3p, and miR-433). Seven of these overlaps can be traced in the CSF up- vs. downregulated comparison (let-7b-5p, miR-I27-3p, miR-136-3p, miR-19b-3p, miR-33I-5p, miR-409-3p, and miR-99a-5p) and four in the plasma up- vs. downregulated comparison (miR-136-3p, miR-22-3p, miR-222, and miR-67I-5p). Remarkably, there are no overlaps between the upand downregulated lists of microRNAs in the serum and PBMC lists.

The similarities between CSF and plasma microRNA profiles continue when comparing the upregulated and downregulated microRNA lists; there are three overlaps between the upregulated lists of microRNAs (miR-136-3p, miR-19b-3p, and miR-7-5p), and three between the downregulated lists of microRNAs 
(miR-I36-3p, miR-409-3p, and miR-485-5p). Thus, it is possible that in plasma, only the changes in miR-rgb-3p, miR-7-5p, miR-409-3p, and miR-485-5p levels accurately reflect the brain-derived CSF microRNAs alteration in PD (Figure $\mathrm{I}$ ).

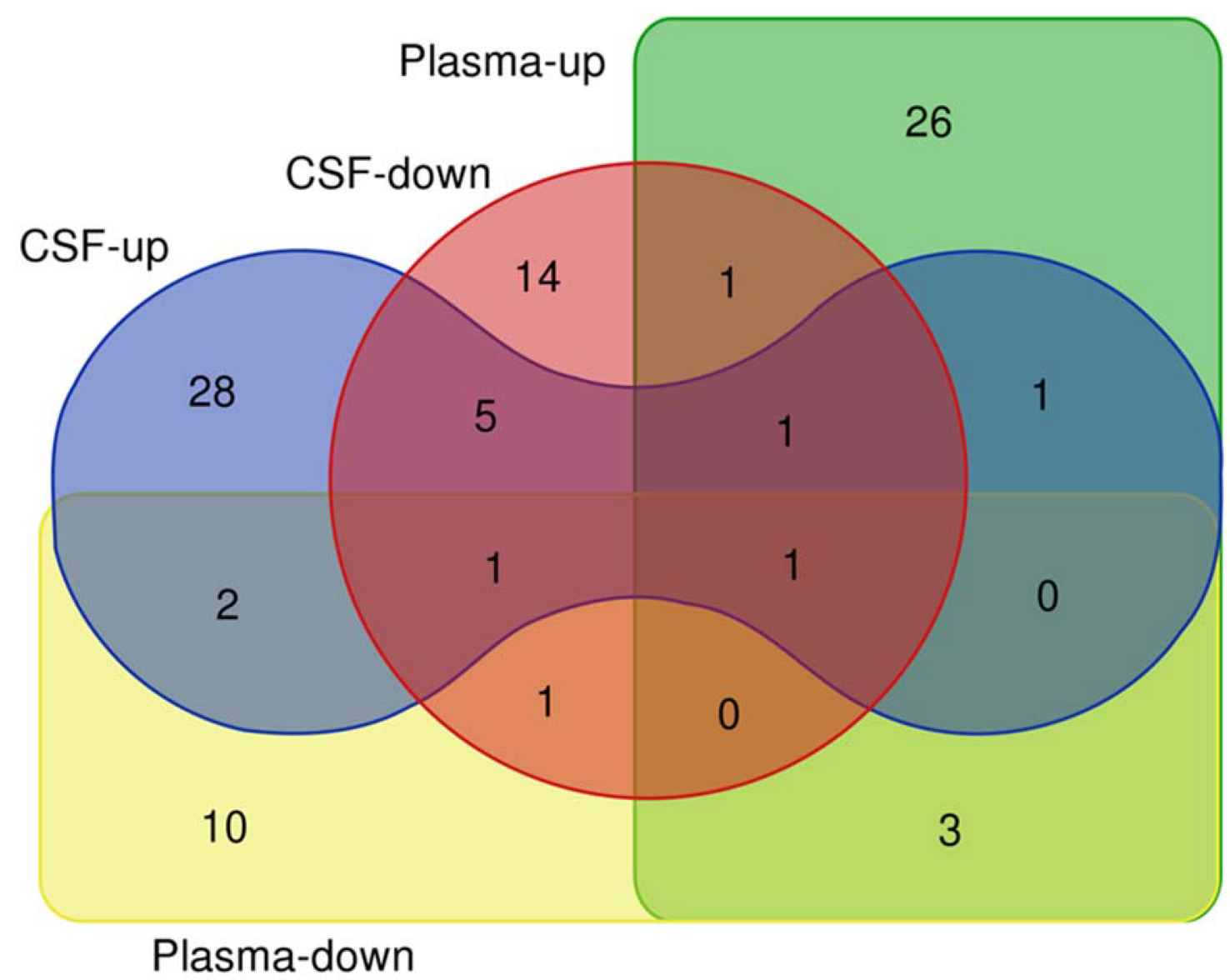

Figure I. Venn diagram depicting microRNAs in CSF and plasma from PD patients.

A similar analysis of CSF, serum, and PBMCs identifies only four overlaps with upregulated microRNAs in the serum (miR-3oa-3p, miR-3oe-3p, miR-33I-5p, and miR-338-3p); there are no overlaps between CSF and PBMCs (Figure 2).

Even more surprising is the comparison between plasma and serum datasets, which identifies one single microRNA (miR-I33b) in the downregulated microRNAs list; furthermore, no concordant changes in microRNAs expression can be identified when plasma and PBMC lists are compared. While upregulated microRNA in serum and PBMC lists show no overlaps, the comparison of the downregulated microRNAs identifies four concordant changes: miR-19b, miR-29b, miR-29c, and miR-3oc (Figure 2). 


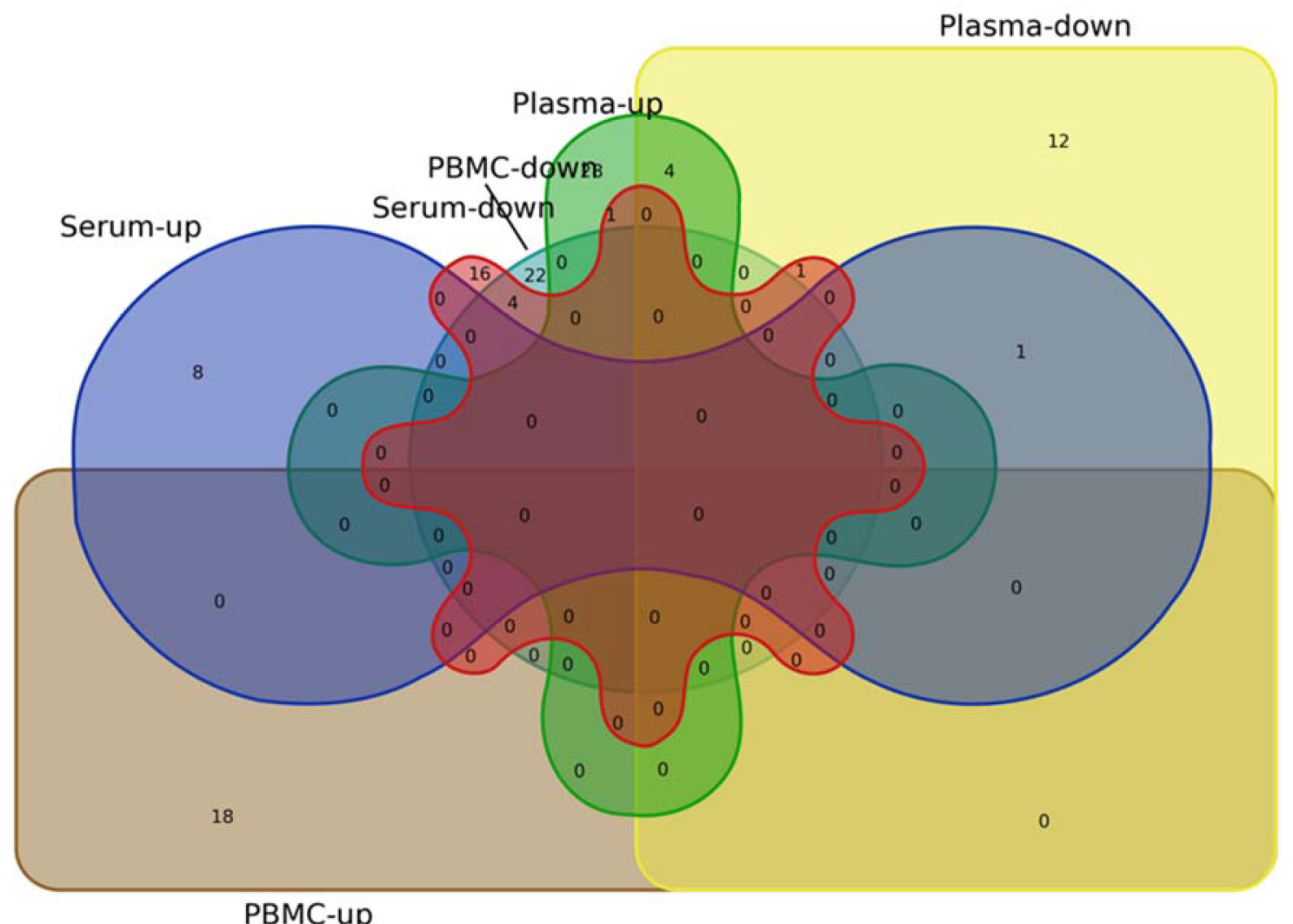

Figure 2. Venn diagram depicting upregulated (left) and downregulated (right) microRNAs in plasma, serum, and PBMCs from PD patients.

\section{Conclusions}

How useful are these microRNA biomarkers in discriminating between PD and non-PD patients? The sensitivity and specificity of the microRNAs identified/analyzed vary widely and, especially when combining several microRNAs, surpasses $90 \%$. We consider the analysis of subsets of circulant extracellular vesicles, which have the potential to refine the diagnostics and augment discrimination accuracy, to be of particular interest. Of note, very few studies have managed to validate their results in independent cohorts and with a different platform.

Despite the poor reproducibility between the studies included in our analysis, the identification of a few microRNAs showing concordant changes in CSF and plasma components is encouraging. More studies combining NGS (for screening), qRT-PCR (for validation), and techniques to isolate subsets of circulant extracellular vesicles would eventually lead to a PD-specific microRNA signature.

Author Contributions: A.R.C.: Conceptualization, Data curation, Formal Analysis, and Writing-Original Draft Preparation; A.I.M.: Data curation and Formal Analysis; I.-O.S.: Conceptualization, Methodology, Writing-Original Draft Preparation, Supervision, Writing-Review and Editing, and Funding Acquisition. All authors have read and agreed to the published version of the manuscript.

Funding: This research received no funding.

Conflicts of Interest: The authors declare no conflicts of interest. 


\section{References}

I. GBD 2016 Parkinson's Disease Collaborators. Global, regional, and national burden of Parkinson's disease, 1990-2016: A systematic analysis for the Global Burden of Disease Study 2016. Lancet Neurol. 2018, 17, 939-953. [CrossRef]

2. Dorsey, E.R.; Constantinescu, R.; Thompson, J.P.; Biglan, K.M.; Holloway, R.G.; Kieburtz, K.; Marshall, F.J.; Ravina, B.M.; Schifitto, G.; Siderowf, A.; et al. Projected number of people with Parkinson disease in the most populous nations, 2005 through 2030. Neurology 2007, 68, 384-386. [CrossRef] [PubMed]

3. Poewe, W.; Seppi, K.; Tanner, C.M.; Halliday, G.M.; Brundin, P.; Volkmann, J.; Schrag, A.E.; Lang, A.E. Parkinson disease. Nat. Rev. Dis. Primers 2o17, 3, I7013. [CrossRef] [PubMed]

4. Armstrong, M.J.; Okun, M.S. Diagnosis and Treatment of Parkinson Disease: A Review. JAMA 2020, 323, 548-560. [CrossRef]

5. Postuma, R.B.; Poewe, W.; Litvan, I.; Lewis, S.; Lang, A.E.; Halliday, G.; Goetz, C.G.; Chan, P.; Slow, E.; Seppi, K.; et al. Validation of the MDS clinical diagnostic criteria for Parkinson's disease. Mov. Disord. 2or8, 33, I6oI-1608. [CrossRef]

6. Suwijn, S.R.; van Boheemen, C.J.; de Haan, R.J.; Tissingh, G.; Booij, J.; de Bie, R.M. The diagnostic accuracy of dopamine transporter SPECT imaging to detect nigrostriatal cell loss in patients with Parkinson's disease or clinically uncertain parkinsonism: A systematic review. EJNMMI Res. 2015, 5, I2. [CrossRef]

7. Fearnley, J.M.; Lees, A.J. Ageing and Parkinson's disease: Substantia nigra regional selectivity. Brain 1991, II4, 2283-230i. [CrossRef]

8. Malek, N.; Swallow, D.; Grosset, K.A.; Anichtchik, O.; Spillantini, M.; Grosset, D.G. Alpha-synuclein in peripheral tissues and body fluids as a biomarker for Parkinson's disease-A systematic review. Acta Neurol. Scand. 2014, $130,59-72$. [CrossRef]

9. Goldman, J.G.; Andrews, H.; Amara, A.; Naito, A.; Alcalay, R.N.; Shaw, L.M.; Taylor, P.; Xie, T.; Tuite, P.; Henchcliffe, C.; et al. Cerebrospinal fluid, plasma, and saliva in the BioFIND study: Relationships among biomarkers and Parkinson's disease Features. Mov. Disord. 2018, 33, 282-288. [CrossRef]

Io. Bartel, D.P. MicroRNAs: Genomics, biogenesis, mechanism, and function. Cell 2004, II6, 28I-297. [CrossRef]

II. Keller, A.; Leidinger, P.; Bauer, A.; Elsharawy, A.; Haas, J.; Backes, C.; Wendschlag, A.; Giese, N.; Tjaden, C.; Ott, K.; et al. Toward the blood-borne miRNome of human diseases. Nat. Methods 2oII, 8, 84I-843. [CrossRef]

12. Doxakis, E. Cell-free microRNAs in Parkinson's disease: Potential biomarkers that provide new insights into disease pathogenesis. Ageing Res. Rev. 2020, 58 , 101023. [CrossRef]

I3. Burgos, K.; Malenica, I.; Metpally, R.; Courtright, A.; Rakela, B.; Beach, T.; Shill, H.; Adler, C.; Sabbagh, M.; Villa, S.; et al. Profiles of extracellular miRNA in cerebrospinal fluid and serum from patients with Alzheimer's and Parkinson's diseases correlate with disease status and features of pathology. PLOS ONE 2014, 9, e94839. [CrossRef]

I4. Sørensen, S.S.; Nygaard, A.B.; Christensen, T. miRNA expression profiles in cerebrospinal fluid and blood of patients with Alzheimer's disease and other types of dementia-An exploratory study. Transl. Neurodegener. 2016, 5, 6. [CrossRef]

I5. Gui, Y.; Liu, H.; Zhang, L.; Lv, W.; Hu, X. Altered microRNA profiles in cerebrospinal fluid exosome in Parkinson disease and Alzheimer disease. Oncotarget 2015, 6, 37043-37053. [CrossRef]

I6. Marques, T.M.; Kuiperij, H.B.; Bruinsma, I.B.; van Rumund, A.; Aerts, M.B.; Esselink, R.A.J.; Bloem, B.R.; Verbeek, M.M. MicroRNAs in Cerebrospinal Fluid as Potential Biomarkers for Parkinson's Disease and Multiple System Atrophy. Mol. Neurobiol. 2o17, 54, 7736-7745. [CrossRef]

17. Qin, L.X.; Tan, J.Q.; Zhang, H.N.; Tang, J.G.; Jiang, B.; Shen, X.M.; Guo, J.F.; Tan, L.M.; Tang, B.; Wang, C.Y. Preliminary study of hsa-miR-626 change in the cerebrospinal fluid of Parkinson's disease patients. J. Clin. Neurosci. 2019, 70, 198-20I. [CrossRef]

I8. Caldi Gomes, L.; Roser, A.E.; Jain, G.; Pena Centeno, T.; Maass, F.; Schilde, L.; May, C.; Schneider, A.; Bähr, M.; Marcus, K.; et al. MicroRNAs from extracellular vesicles as a signature for Parkinson's disease. Clin. Transl. Med. 202I, $I I$, e357. [CrossRef]

19. Dos Santos, M.C.T.; Barreto-Sanz, M.A.; Correia, B.R.S.; Bell, R.; Widnall, C.; Perez, L.T.; Berteau, C.; Schulte, C.; Scheller, D.; Berg, D.; et al. miRNA-based signatures in cerebrospinal fluid as potential diagnostic tools for early stage Parkinson's disease. Oncotarget 2018, g, I7455-17465. [CrossRef]

20. Xu, B.; Zhang, Y.; Du, X.F.; Li, J.; Zi, H.X.; Bu, J.W.; Yan, Y.; Han, H.; Du, J.L. Neurons secrete miR-I32-containing exosomes to regulate brain vascular integrity. Cell Res. 2o17, 27, 882-897. [CrossRef]

2I. Balusu, S.; Van Wonterghem, E.; De Rycke, R.; Raemdonck, K.; Stremersch, S.; Gevaert, K.; Brkic, M.; Demeestere, D.; Vanhooren, V.; Hendrix, A.; et al. Identification of a novel mechanism of blood-brain communication during peripheral inflammation via choroid plexus-derived extracellular vesicles. EMBO Mol. Med. 2016, 8, i162-II83. [CrossRef] [PubMed]

22. Margis, R.; Margis, R.; Rieder, C.R. Identification of blood microRNAs associated to Parkinsonǐs disease. J. Biotechnol. 20II, I52, 96-IoI. [CrossRef] [PubMed] 
23. Ravanidis, S.; Bougea, A.; Papagiannakis, N.; Koros, C.; Simitsi, A.M.; Pachi, I.; Breza, M.; Stefanis, L.; Doxakis, E. Validation of differentially expressed brain-enriched microRNAs in the plasma of PD patients. Ann. Clin. Transl. Neurol. 2020, 7, I594-I607. [CrossRef] [PubMed]

24. Ravanidis, S.; Bougea, A.; Papagiannakis, N.; Maniati, M.; Koros, C.; Simitsi, A.M.; Bozi, M.; Pachi, I.; Stamelou, M.; Paraskevas, G.P.; et al. Circulating Brain-enriched MicroRNAs for detection and discrimination of idiopathic and genetic Parkinson's disease. Mov. Disord. 2020, 35, 457-467. [CrossRef]

25. Grossi, I.; Radeghieri, A.; Paolini, L.; Porrini, V.; Pilotto, A.; Padovani, A.; Marengoni, A.; Barbon, A.; Bellucci, A.; Pizzi, M.; et al. MicroRNA-34a-sp expression in the plasma and in its extracellular vesicle fractions in subjects with Parkinson's disease: An exploratory study. Int. J. Mol. Med. 2o2I, 47, 533-546. [CrossRef]

26. Cosín-Tomás, M.; Antonell, A.; Lladó, A.; Alcolea, D.; Fortea, J.; Ezquerra, M.; Lleó, A.; Martí, M.J.; Pallàs, M.; Sanchez-Valle, R.; et al. Plasma miR-34a-5p and miR-545-3p as Early Biomarkers of Alzheimer's Disease: Potential and Limitations. Mol. Neurobiol. 2017, 54, 5550-5562. [CrossRef]

27. Cardo, L.F.; Coto, E.; de Mena, L.; Ribacoba, R.; Moris, G.; Menéndez, M.; Alvarez, V. Profile of microRNAs in the plasma of Parkinson's disease patients and healthy controls. J. Neurol. 2013, 260, 1420-I422. [CrossRef]

28. Zhang, X.; Yang, R.; Hu, B.L.; Lu, P.; Zhou, L.L.; He, Z.Y.; Wu, H.M.; Zhu, J.H. Reduced Circulating Levels of miR-433 and miR-133b Are Potential Biomarkers for Parkinson's Disease. Front. Cell. Neurosci. 2017, II, 170. [CrossRef]

29. Li, N.; Pan, X.; Zhang, J.; Ma, A.; Yang, S.; Ma, J.; Xie, A. Plasma levels of miR-I37 and miR-I24 are associated with Parkinson's disease but not with Parkinson's disease with depression. Neurol. Sci. 2017, 38, 76I-767. [CrossRef]

3o. Khoo, S.K.; Petillo, D.; Kang, U.J.; Resau, J.H.; Berryhill, B.; Linder, J.; Forsgren, L.; Neuman, L.A.; Tan, A.C. Plasma-based circulating MicroRNA biomarkers for Parkinson's disease. J. Parkinsons Dis. 2or2, 2, 32I-33I. [CrossRef]

3I. Chen, L.; Yang, J.; Lü, J.; Cao, S.; Zhao, Q.; Yu, Z. Identification of aberrant circulating miRNAs in Parkinson’s disease plasma samples. Brain Behav. 2018, 8, eoo94I. [CrossRef]

32. Uwatoko, H.; Hama, Y.; Iwata, I.T.; Shirai, S.; Matsushima, M.; Yabe, I.; Utsumi, J.; Sasaki, H. Identification of plasma microRNA expression changes in multiple system atrophy and Parkinson's disease. Mol. Brain 2or9, I2, 49. [CrossRef]

33. Yang, Z.; Li, T.; Cui, Y.; Li, S.; Cheng, C.; Shen, B.; Le, W. Elevated Plasma microRNA-Ios-sp Level in Patients With Idiopathic Parkinson's Disease: A Potential Disease Biomarker. Front. Neurosci. 2o19, I3, 218. [CrossRef]

34. Zhao, N.; Jin, L.; Fei, G.; Zheng, Z.; Zhong, C. Serum microRNA-I3zb is associated with low ceruloplasmin levels in Parkinson's disease. Parkinsonism Relat. Disord. 2or4, 20, II77-II8o. [CrossRef]

35. Dong, H.; Wang, C.; Lu, S.; Yu, C.; Huang, L.; Feng, W.; Xu, H.; Chen, X.; Zen, K.; Yan, Q.; et al. A panel of four decreased serum microRNAs as a novel biomarker for early Parkinson's disease. Biomarkers 2016, 2I, I29-I37. [CrossRef]

36. Shu, Y.; Qian, J.; Wang, C. Aberrant expression of microRNA-I32-3p and microRNA-I46a-sp in Parkinson's disease patients. Open Life Sci. 2o20, $15,647-653$. [CrossRef]

37. Vallelunga, A.; Ragusa, M.; Di Mauro, S.; Iannitti, T.; Pilleri, M.; Biundo, R.; Weis, L.; Di Pietro, C.; De Iuliis, A.; Nicoletti, A.; et al. Identification of circulating microRNAs for the differential diagnosis of Parkinson's disease and Multiple System Atrophy. Front. Cell. Neurosci. 2or4, 8, i56. [CrossRef]

38. Botta-Orfila, T.; Morató, X.; Compta, Y.; Lozano, J.J.; Falgàs, N.; Valldeoriola, F.; Pont-Sunyer, C.; Vilas, D.; Mengual, L.; Fernández, M.; et al. Identification of blood serum micro-RNAs associated with idiopathic and LRRK2 Parkinson's disease. J. Neurosci. Res. 2014, 92, I07I-IO77. [CrossRef]

39. Bai, X.; Tang, Y.; Yu, M.; Wu, L.; Liu, F.; Ni, J.; Wang, Z.; Wang, J.; Fei, J.; Wang, W.; et al. Downregulation of blood serum microRNA 29 family in patients with Parkinson's disease. Sci. Rep. 2or7, 7, 54II. [CrossRef]

40. Han, L.; Tang, Y.; Bai, X.; Liang, X.; Fan, Y.; Shen, Y.; Huang, F.; Wang, J. Association of the serum microRNA-29 family with cognitive impairment in Parkinson's disease. Aging 2020, I2, I3518-13528. [CrossRef]

4I. Cao, X.Y.; Lu, J.M.; Zhao, Z.Q.; Li, M.C.; Lu, T.; An, X.S.; Xue, L.J. MicroRNA biomarkers of Parkinson's disease in serum exosome-like microvesicles. Neurosci. Lett. 2017, 644, 94-99. [CrossRef] [PubMed]

42. Ding, H.; Huang, Z.; Chen, M.; Wang, C.; Chen, X.; Chen, J.; Zhang, J. Identification of a panel of five serum miRNAs as a biomarker for Parkinson's disease. Parkinsonism Relat. Disord. 2016, 22, 68-73. [CrossRef] [PubMed]

43. Ma, W.; Li, Y.; Wang, C.; Xu, F.; Wang, M.; Liu, Y. Serum miR-22ı serves as a biomarker for Parkinson's disease. Cell. Biochem. Funct. 2o16, 34, 5II-515. [CrossRef] [PubMed]

44. Jin, L.; Wan, W.; Wang, L.; Wang, C.; Xiao, J.; Zhang, F.; Zhao, J.; Wang, J.; Zhan, C.; Zhong, C. Elevated microRNA- $520 d-5 p$ in the serum of patients with Parkinson's disease, possibly through regulation of cereloplasmin expression. Neurosci. Lett. 2or8, 687, 88-93. [CrossRef] [PubMed]

45. Behbahanipour, M.; Peymani, M.; Salari, M.; Hashemi, M.S.; Nasr-Esfahani, M.H.; Ghaedi, K. Expression Profiling of Blood microRNAs 885, 36I, and 17 in the Patients with the Parkinson's disease: Integrating Interaction Data to Uncover the Possible Triggering Age-Related Mechanisms. Sci. Rep. 2019, 9, I3759. [CrossRef] 
46. Martins, M.; Rosa, A.; Guedes, L.C.; Fonseca, B.V.; Gotovac, K.; Violante, S.; Mestre, T.; Coelho, M.; Rosa, M.M.; Martin, E.R.; et al. Convergence of miRNA expression profiling, $\alpha$-synuclein interacton and GWAS in Parkinson's disease. PLoS ONE 20II, 6, e25443. [CrossRef]

47. Caggiu, E.; Paulus, K.; Mameli, G.; Arru, G.; Sechi, G.P.; Sechi, L.A. Differential expression of miRNA is5 and miRNA I46a in Parkinson's disease patients. eNeurologicalSci 2018, I3, I-4. [CrossRef]

48. Thome, A.D.; Harms, A.S.; Volpicelli-Daley, L.A.; Standaert, D.G. microRNA-I55 Regulates Alpha-Synuclein-Induced Inflammatory Responses in Models of Parkinson Disease. J. Neurosci. 2016, 36, 2383-2390. [CrossRef]

49. Soreq, L.; Salomonis, N.; Bronstein, M.; Greenberg, D.S.; Israel, Z.; Bergman, H.; Soreq, H. Small RNA sequencing-microarray analyses in Parkinson leukocytes reveal deep brain stimulation-induced splicing changes that classify brain region transcriptomes. Front. Mol. Neurosci. 2o13, 6, io. [CrossRef]

50. Serafin, A.; Foco, L.; Zanigni, S.; Blankenburg, H.; Picard, A.; Zanon, A.; Giannini, G.; Pichler, I.; Facheris, M.F.; Cortelli, P.; et al. Overexpression of blood microRNAs I03a, 3ob, and 29a in L-dopa-treated patients with PD. Neurology 2015, 84, 645-653. [CrossRef]

5I. Fazeli, S.; Motovali-Bashi, M.; Peymani, M.; Hashemi, M.S.; Etemadifar, M.; Nasr-Esfahani, M.H.; Ghaedi, K. A compound downregulation of SRRM2 and miR-27a-3p with upregulation of miR-27b-3p in PBMCs of Parkinson's patients is associated with the early stage onset of disease. PLOS ONE 2020, 15 , e0240855. [CrossRef]

52. Baghi, M.; Rostamian Delavar, M.; Yadegari, E.; Peymani, M.; Pozo, D.; Hossein Nasr-Esfahani, M.; Ghaedi, K. Modified level of miR-376a is associated with Parkinson's disease. J. Cell. Mol. Med. 2020, 24, 2622-2634. [CrossRef]

53. Wang, K.; Yuan, Y.; Cho, J.H.; McClarty, S.; Baxter, D.; Galas, D.J. Comparing the MicroRNA spectrum between serum and plasma. PLoS ONE 2or2, 7, e4156I. [CrossRef]

54. Blondal, T.; Jensby Nielsen, S.; Baker, A.; Andreasen, D.; Mouritzen, P.; Wrang Teilum, M.; Dahlsveen, I.K. Assessing sample and miRNA profile quality in serum and plasma or other biofluids. Methods 2013, 59, SI-S6. [CrossRef]

55. Yeri, A.; Courtright, A.; Danielson, K.; Hutchins, E.; Alsop, E.; Carlson, E.; Hsieh, M.; Ziegler, O.; Das, A.; Shah, R.V.; et al. Evaluation of commercially available small RNASeq library preparation kits using low input RNA. BMC Genom. 2or8, 19 , 331. [CrossRef]

${ }_{0}{ }_{2021}$ Copyright by the authors. Licensed as an open access article using a CC BY 4.o license.

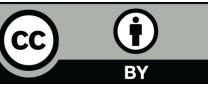

